Abstracta Iranica

Revue bibliographique pour le domaine irano-aryen

Volume 40-41 | 2019

Comptes rendus des publications de 2017-2018

\title{
David J. Roxburgh (ed.). An Album of Artists' Drawings from Qajar Iran
}

\section{Iván Szántó}

\section{Q OpenEdition \\ 1 Journals}

\section{Electronic version}

URL: http://journals.openedition.org/abstractairanica/50622

DOI: 10.4000/abstractairanica.50622

ISBN: 1961-960X

ISSN: 1961-960X

Publisher:

CNRS (UMR 7528 Mondes iraniens et indiens), Éditions de l'IFRI

Electronic reference

Iván Szántó, "David J. Roxburgh (ed.). An Album of Artists' Drawings from Qajar Iran", Abstracta Iranica [Online], Volume 40-41 | 2019, document 21, Online since 30 December 2019, connection on 18 April 2021. URL: http://journals.openedition.org/abstractairanica/50622 ; DOI: https://doi.org/10.4000/ abstractairanica.50622

This text was automatically generated on 18 April 2021.

Tous droits réservés 


\title{
David J. Roxburgh (ed.). An Album of Artists' Drawings from Qajar Iran
}

\author{
Iván Szántó
}

\section{REFERENCES}

David J. Roxburgh (ed.). An Album of Artists' Drawings from Qajar Iran. Cambridge, MA:

Harvard Art Museums, 2017, 174 p., ISBN: 9781891771729

1 This lavish volume may be the first monograph to have been dedicated to Qajar drawings and sketches. Therefore, while the book apparently revolves around a single album (Harvard Art Museums / Arthur M. Sackler Museum, Alpheus Hyatt Purchasing Fund, 1960.161), readers will soon recognise its more general underlying objective throughout the chapters, i.e., the place of drawing in the repertoire of Qajar art. The impressive size of the book ensures that the reproduction of each folio appears at actual size. Preceded by 12 short studies and two appendices (results of a graduate seminar at Harvard in 2015), the album is published in facsimile, including front and back covers, and 57 double-sided folios. It may have been assembled in the early-20th century using mid-18th-century to early 20th-century materials and it seems to have made its way soon thereafter to the Western art market, first somewhere in the AustroHungarian Empire, then travelling overseas to enter Harvard in 1960, where it would attract little attention until the present publication.

2 Issues regarding the provenance, organisation, and layout of the album are assessed in the first chapter (David J. Roxburgh: "The Harvard Qajar Album - From Cover to Cover", pp.15-30), while strategies of copying paintings and photography assume centre stage in "Pouncing and the Materiality of Image Transfer" by Trent Barnes (pp. 31-34). The next chapter (Mycah Braxter: “Assimilation and Rupture: Qajar Ink and Watercolor Technique", pp. 35-39) takes into consideration the coexistence of two media in several drawings of the album, as well as the functional differences between these two techniques. Gwendolyn Collaço demonstrates how the album's drawings 
contrast the sartorial make-up of a mythological, yet local, Iranian past, and the contemporary, yet distant and foreign, European ("farangi") fashion trends ("Crafting Time through Dress: A Pastiche of Periods and Regions", pp. 40-44). The importance of devotional images and the depiction of different protagonists of urban life are examined in the next two chapters, respectively (Farhad Dokhani: "Religious Subjects and Themes: Shi'i Islam and the Revival of Iranian Sufism and Dervishes", pp. 45-49; Bronwen Gulkis: "Trades and Professions", pp. 50-54). The origin of papers used in the album, in particular the support of 16 drawings discussed in Gulkis' study and showing the watermark "GM" (which can be identified as Giorgio Magnani), is painstakingly analysed by Penley Knipe in "The Papers in the Harvard Album" (pp. 55-59). Mary McWilliams concentrates on a subgroup of drawings in the album that can be directly linked to extant lacquer paintings by Najaf 'Alī and his workshop: these identical compositions have been transmitted from one medium to the other with the help of hundreds of piercings visible along the contours of the album drawings ("Reflections of the Najaf Circle of Artists in Isfahan", pp. 60-67).

Contrasting the traditional writer's implements depicted on an oil painting, entitled Fortune-teller (Tehran, Șa' dābād Museum), by Muḥammad Ghaffārī Kamāl al-Mulk, with the modernism of the painting itself, Sarah Mirseyedi's essay takes a more theoretical approach towards the album ("Aesthetic Innovation and Conditions of Modernity in 19th-century Iran", pp.68-71), while Veronika Poier's study compares depictions of royalty in the album and in other genres and observes a general tendency during the Qajar period from an impersonal towards a more personalised rendering of the ruler ("Cross Cultural Modernity: Military Reform and the Image of the Shah", pp. 72-77). The legality of romantic and sexual affairs is the theme of the next chapter (Mira Xenia Schwerda: "Amorous Couples: Depictions of Permitted and Prohibited Love", pp. 78-83), as depicted by a group of drawings in the album and beyond, where the frequent appearance of European males and African nannies further complicates the moral ambiguity of the subject. In the last chapter, Meredyth Winter discusses the ease with which subjects and motifs can travel between the different media of Qajar art, and locates drawing in an intermediary position ("The Image and the Drawing in Qajar Iran", pp. 84-89). The two appendices list the watermarks in the album and provide a checklist of known lacquer objects from the Najaf circle which can be linked to drawings in the album.

\section{AUTHORS}

\section{IVÁN SZÁNTÓ}

Eötvös Loránd University, Budapest 